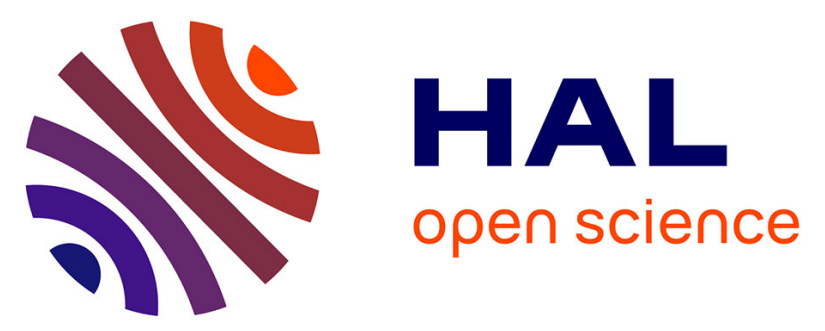

\title{
Evaluation of antiplasmodial and antileishmanial activities of herbal medicine Pseudelephantopus spiralis (Less.) Cronquist and isolated hirsutinolide-type sesquiterpenoids
}

Cynthia Girardi, Nicolas Fabre, Lucie Paloque, Arba Pramundita Ramadani, Françoise Benoit-Vical, German Gonzalez-Aspajo, Mohamed Haddad, Elsa Rengifo, Valérie Jullian

\section{- To cite this version:}

Cynthia Girardi, Nicolas Fabre, Lucie Paloque, Arba Pramundita Ramadani, Françoise Benoit-Vical, et al.. Evaluation of antiplasmodial and antileishmanial activities of herbal medicine Pseudelephantopus spiralis (Less.) Cronquist and isolated hirsutinolide-type sesquiterpenoids. Journal of Ethnopharmacology, 2015, 170, pp.167-174. 10.1016/j.jep.2015.05.014 . hal-01925138

\author{
HAL Id: hal-01925138 \\ https://hal.science/hal-01925138
}

Submitted on 11 May 2021

HAL is a multi-disciplinary open access archive for the deposit and dissemination of scientific research documents, whether they are published or not. The documents may come from teaching and research institutions in France or abroad, or from public or private research centers.
L'archive ouverte pluridisciplinaire HAL, est destinée au dépôt et à la diffusion de documents scientifiques de niveau recherche, publiés ou non, émanant des établissements d'enseignement et de recherche français ou étrangers, des laboratoires publics ou privés. 


\section{Evaluation of antiplasmodial and antileishmanial activities of herbal medicine Pseudelephantopus spiralis (Less.) Cronquist and isolated hirsutinolide-type sesquiterpenoids}

Cynthia Girardi ${ }^{a, b}$, Nicolas Fabre ${ }^{a, b}$, Lucie Paloque ${ }^{a, b}$, Arba Pramundita Ramadani $^{c, d}$, Françoise Benoit Vical ${ }^{c, d}$, German Gonzalez Aspajo ${ }^{a, b}$, Mohamed Haddad $^{\mathrm{a}, \mathrm{b}}$, Elsa Rengifo ${ }^{\mathrm{e}}$, Valérie Jullian ${ }^{\mathrm{a}, \mathrm{f}}$

${ }^{a}$ Université de Toulouse, UPS, UMR 152 Pharma-DEV, Université Toulouse 3, Faculté des Sciences Pharmaceutiques, F-31062 Toulouse cedex 09, France

${ }^{\mathrm{b}}$ Institut de Recherche pour le Développement (IRD), UMR 152 Pharma-DEV, F-31062 Toulouse cedex 09, France

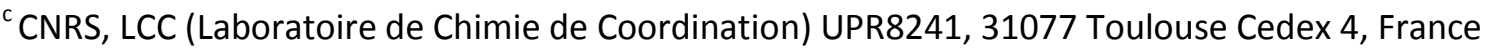

${ }^{d}$ Université de Toulouse, UPS, INPT, 31077 Toulouse Cedex 4, France

e Programa de Investigación en Biodiversidad Amazónica (PIBA). Instituto de Investigaciones de la Amazonía Peruana-IIAP. Av. Abelardo Quiñones km 4.5, Iquitos, Perú.

${ }^{\mathrm{f}}$ Institut de Recherche pour le Développement (IRD), UMR 152 Pharma-DEV, Mission IRD Casilla 181209, Lima, Peru

\section{Abstract}

\section{Ethnopharmacological relevance}

Pseudelephantopus spiralis (Less.) Cronquist is distributed in the Caribbean, Mesoamerica and Latin America. Preparations of the plant are traditionally used in Latin America for the treatment of various diseases including fever, malaria, and spleen or liver inflammations.

\section{Materials and methods}

Aerial parts of $P$. spiralis were extracted with either ethanol or distilled water. Seven hirsutinolidetype sesquiterpenoids were isolated: 8-acetyl-13-ethoxypiptocarphol (1), diacetylpiptocarphol (2), piptocarphins A (3), $F \quad(4)$ and $D$ (5), (15*,4R*,85*,10R*)-1,4-epoxy-13-ethoxy-1,8,10trihydroxygermacra-5E,7(11)-dien-6,12-olide (6), and piptocarphol (7). Extracts and isolated compounds $(\mathbf{2}, \mathbf{3}, \mathbf{5 - 7})$ were screened for their in vitro antiplasmodial activity against the chloroquine-resistant Plasmodium falciparum strain FcM29-Cameroon and antileishmanial activity against three stages of Leishmania infantum. Their cytotoxicities were also evaluated against healthy VERO cell lines and J774A.1 macrophages, the host cells of the Leishmania parasites in humans. 


\section{Results}

Aqueous extracts showed a greater inhibitory effect than alcoholic extracts, with $\mathrm{IC}_{50}$ on $P$. falciparum of $3.0 \mu \mathrm{g} / \mathrm{mL}$ versus $21.1 \mu \mathrm{g} / \mathrm{mL}$, and on L. infantum of $13.4 \mu \mathrm{g} / \mathrm{mL}$ versus $>50 \mu \mathrm{g} / \mathrm{mL}$. Both extracts were found to be cytotoxic to VERO cells $\left(\mathrm{CC}_{50}<3 \mu \mathrm{g} / \mathrm{mL}\right)$. Sesquiterpene lactones 2 and 3 showed the best activity against both parasites but failed in selectivity. Carbon 8 hydroxylated hirsutinolides 5-7 presented the particularity of exhibiting two conformers observed in solution during extensive NMR analyses in $\mathrm{CD}_{3} \mathrm{OD}$ and UHPLC-MS. The presence of a hydroxyl function at $\mathrm{C}-8$ decreased the activity of 5-7 on the two parasites and also on VERO cells.

\section{Conclusion}

The antiplasmodial activity displayed by the aqueous extract explains the traditional use of Pseudelephantopus spiralis in the treatment of malaria. This activity seems to be attributable to the presence of sesquiterpene lactones $\mathbf{2}$ and $\mathbf{3}$, the most active against $P$. falciparum. Aqueous extract and compounds 2, $\mathbf{3}$ and $\mathbf{6}$ were also active against $L$. infantum but lacked in selectivity due to their cytotoxicity towards macrophages. Exploring the safety and antiplasmodial efficacy of this traditional remedy will require further toxicological and in vivo studies in the light of the cytotoxicity towards healthy cell lines displayed by the aqueous extract and compounds $\mathbf{2}$ and $\mathbf{3}$.

\section{Introduction}

Tropical protozoan diseases are currently a major public health problem throughout the world. Malaria, caused by Plasmodium species is the most devastating parasitic disease with 198 million cases estimated in 2013 and about 600000 deaths mainly due to P. falciparum ("WHO | Malaria Fact sheet N94," n.d.). Leishmaniasis, identified as a "Neglected Tropical Disease" by the World Health Organization, is endemic in 98 countries and territories, with a number of new cases estimated at 1.3 million per year ("WHO | Leishmaniasis Fact sheet $\mathrm{N}^{\circ} 375$," n.d.). Leishmania infantum, the agent responsible for the lethal visceral form of Leishmaniasis (Romero and Boelaert, 2010) is present in Latin America and in the Old World (WHO Expert Committee on the Control of the Leishmaniases and Meeting, 2010). Many plants are traditionally used in South American folk medicine for the treatment of these two important parasitoses (Domingues Passero et al., 2014; Kvist et al., 2006; Valadeau et al., 2009; Willcox and Bodeker, 2004). Most of the drugs marketed for use against malaria are directly or indirectly derived from natural products (Cragg and Newman, 2013), and plant secondary metabolites still constitute a promising source of new antiprotozoal leads and/or drugs (Fournet and Munoz, 2002; Schmidt et al., 2012a, 2012b; Singh et al., 2014).

Pseudelephantopus spiralis (Less.) Cronquist belongs to the Asteraceae family and is one of the two species that make up the genus Pseudelephantopus (Pruski, 2011). The plant is distributed in the Caribbean, Mesoamerica and Latin America (Macbride, 1936), and is considered a weed (Canizales et al., 2010; Ochoa and Andrade, 2003; Tye, 2001). The species, named Mata pasto or Pasto mula, is traditionally used in Peru to treat menstrual cramps and as liver depurative ("Internal report: base de datos de las plantas medicinales. 2010. IIAP," n.d.). In southern Equator the whole plant is cooked and used by oral administration to treat fever, high blood pressure, shivering fits and malaria (Bussmann and Sharon, 2006). In Colombia, infusions of roots or whole plant were dispensed as a beverage or in baths, in combination with other plants, to treat malaria, spleen and liver 
inflammations (Blair Trujillo and Madrigal, 2005). Moreover Pseudelephantopus spicatus (Juss. ex Aubl.) C.F. Baker, the second and only other species in the Pseudelephantopus genus, is also used in Peruvian Amazonia as a traditional antileishmanial remedy (Odonne et al., 2013, 2011). A previous phytochemical investigation of this latter species led to the isolation of two hirsutinolide-type sesquiterpene lactones exhibiting strong antileishmanial activities (Odonne et al., 2011). Based on this result, $P$. spiralis was expected to synthesize structurally related active compounds hence we decided to conduct the present phytochemical investigation of $P$. spiralis to evaluate its antiplasmodial and antileishmanial potential and thus confirm the relevance of its traditional use. In this context, aqueous and ethanolic extracts of the aerial parts of $P$. spiralis were prepared and bioguided assay led to the isolation and identification of seven hirsutinolide-type sesquiterpenes lactones. They were identified as 8-acetyl-13-ethoxypiptocarphol (1), diacetylpiptocarphol (2), piptocarphins $A$ (3), $F \quad(4)$ and $D$ (5), (15*,4R*,85*,10R*)-1,4-epoxy-13-ethoxy-1,8,10trihydroxygermacra-5E,7(11)-dien-6,12-olide (6), and piptocarphol (7). The extracts and pure compounds were tested for their in vitro antiprotozoal activities against two parasite species: a chloroquine-resistant strain of Plasmodium falciparum and the promastigote and axenic amastigote stages of Leishmania infantum. The samples were also assessed for their cytotoxicity on VERO cells and macrophages in order to determine their selectivity indices.

\section{Materials and methods}

\subsection{Plant material}

Two batches of $P$. spiralis (Less.) Cronquist aerial parts were collected from a permanent plot in the Medicinal plant garden of the Reserva Allpahuayo-Mishana, Carretera Iquitos-Nauta, kilometer 28, Loreto, Peru, in May 2012 and May 2013. Plant authentication was confirmed during the collection by Elsa Rengifo, botanist at the Instituto de Investigaciones de la Amazonía Peruana (IIAP). A voucher is kept as reference in Université Paul Sabatier (Toulouse, France), faculty of pharmaceutical science, department of pharmacognosy under the number CG111.

\subsection{General experimental procedure}

The ${ }^{1} \mathrm{H}$ - and ${ }^{13} \mathrm{C}$-NMR spectra (Fig. S1-S19 in the supplementary data) were recorded on Bruker Avance $300 \mathrm{MHz}$ or $500 \mathrm{MHz}$ instrument with samples diluted in $\mathrm{CDCl}_{3}$ or $\mathrm{CD}_{3} \mathrm{OD}$. Mass spectra were acquired using a LTQ Orbitrap XL mass spectrometer (Thermo Fisher Scientific). The system was equipped with an electrospray source operating in the positive ion mode. The apparatus was controlled by Xcalibur software version 2.0.7. Chromatography columns were filled with Merck silica gel 60A $(40-63 \mu \mathrm{m})$. Reverse phase separations were performed on Agilent C18 Bond Elut SPE cartridge using a Varian Vac Elut SPS 24 Manifold system, and a ILMVAC LVS 101 Pump. Analytical TLC were achieved on precoated Kieselgel $60 \mathrm{~F}_{254} 20 \times 20 \mathrm{~cm}$ plates (Merck, $0.5 \mathrm{~mm}$ thin) using UV 254 $\mathrm{nm}$ and $1 \%$ vanillin/10\% sulphuric acid reagent in $\mathrm{EtOH}$ for visualization. Chlorophylls were removed on Fisher Chemical activated charcoal. Freeze drying was performed on a Labconco ${ }^{T M}$ Lyph-Lock $6^{T M}$ 7753001 lyophilizer. Preparative HPLC were carried out on a LaChrom Merck Hitachi system, 
consisting of a LaChrom L-7100 Pump, a L-7455 DAD, a D-7000 Interface and using a Phenomenex Luna $5 \mu \mathrm{C} 18(2) 100 \AA, 250 \times 10 \mathrm{~mm}$ column.

\subsection{Drugs or reagents}

Solvents $\mathrm{CH}_{2} \mathrm{Cl}_{2}, \mathrm{CH}_{3} \mathrm{CN}$, and $\mathrm{MeOH}$ (HPLC grade) were purchassed from Fisher Chemical (Fischer Scientific, France). Toluene, ethyl acetate and petroleum ether were analytical reagent grade from Fisher Chemical (Fisher Scientific, France). Formic acid (99-100\%), $95 \%$ ethanol technical grade were from Prolabo (VWR Chemicals, France). Sulphuric acid $96 \%$ and vanillin 99\% used for CCM development were from Acros Organics (Fisher Scientific, France). Extraction and separation used distilled water. High-purity water (18.2 M $\Omega . c m$; total organic carbon: $2 \mathrm{ppb}$ ) was obtained from a Milli-Q water purification system (Millipore, Merck, France) and used for analytical and preparative HPLC. DMSO used for biological assays was from Fisher Bioreagents (Fischer Scientific, France). Reference drugs amphotericin B, miltefosin, pentamidine, doxorubicin, chloroquine, artemisinin and antibiotics penicillin, streptomycin and geneticin as MTT reagent (>97.5\%) used for the biological assays were purchased from Sigma Aldrich (France). Media RPMI 1640 and MAA-20, foetal calf serum (FCS) and L-glutamine used for the biological assays were purchased from Gibco (Fischer Scientific, France).

\subsection{Preparation of the crude extracts:}

Aerial parts of the two batches of $P$. spiralis were dried in the dark, at room temperature before being reduced to powder.

Preparation of the aqueous extract: Powdered aerial parts (353 g) were extracted with boiling distilled water $(4 \mathrm{~L})$ for 10 minutes. The aqueous extract was then frozen at $-20^{\circ} \mathrm{C}$ and lyophilized for $230 \mathrm{~h}$ to give $27.0 \mathrm{~g}$ of residue (yield $7.6 \% \mathrm{w} / \mathrm{w}$ ). The extract was then stored in the dark in sterile universal tubes until use.

Preparation of the ethanolic extract: Powdered aerial parts $(2.1 \mathrm{~g})$ were extracted under stirring with $95 \% \mathrm{EtOH}(80 \mathrm{~mL})$ for $24 \mathrm{~h}$ at room temperature. Solvent was removed under reduced pressure at $40^{\circ} \mathrm{C}$ to give $71 \mathrm{mg}$ of dry residue $(3.4 \% \mathrm{w} / \mathrm{w})$. The extract was then stored as described above.

\subsection{Isolation and identification of pure compounds:}

Procedure A: isolation of compounds 1, 3, 4, 5, 6, 7: Powdered aerial parts ( $374 \mathrm{~g}$ ) were extracted with EtOH $(5 \times 3 \mathrm{~L})$ at room temperature for $48 \mathrm{~h}$ to give $30.7 \mathrm{~g}$ of dry residue (yield $8.2 \% \mathrm{w} / \mathrm{w}$ ). The residue was suspended in $800 \mathrm{~mL}$ of a $\mathrm{H}_{2} \mathrm{O}-\mathrm{MeOH}$ 3:1 mixture and extracted with petroleum ether $(6 \times 600 \mathrm{~mL})$. The lower phase was discarded and evaporation under reduced pressure of the upper phase gave rise to $4.32 \mathrm{~g}$ of residue which was chromatographed on a silica gel $(200 \mathrm{~g})$ column using a toluene gradient containing increasing amounts of ethyl acetate (0-100 \%) followed by ethyl acetate-MeOH 1:1 as eluting solvents. This afforded 12 fractions. In order to eliminate chlorophylls and other pigments, fractions 7 to $10(80 \%$ toluene to $20 \%)$ were pooled $(968.2 \mathrm{mg})$ and suspended 
in $500 \mathrm{~mL} \mathrm{MeOH}$ containing $4 \mathrm{~g}$ of active charcoal for $1 \mathrm{~h}$. The suspension was filtered on $0.45 \mu \mathrm{m}$ nylon filter and a chlorophyll free residue $(322 \mathrm{mg}$ ) was obtained after evaporation of the methanol. It was suspended in $2 \mathrm{~mL}$ of $\mathrm{MeOH}-\mathrm{H}_{2} \mathrm{O}$ 1:1 and subjected to SPE C18 cartridge (10 g) under vacuum ( $\mathrm{P}=5 \mathrm{~mm} \mathrm{Hg}$ ) then eluted with increasing amounts of $\mathrm{MeOH}$ in $\mathrm{H}_{2} \mathrm{O}$ (50-100 \%). This afforded 13 fractions (A to $M$ ). Fraction $A\left(113 \mathrm{mg}\right.$ ) was chromatographed on SPE C18 cartridge (10 g) with $\mathrm{H}_{2} \mathrm{O}$ and increasing amounts of $\mathrm{MeOH}$ to give 15 fractions (A1-A15). Fraction $\mathrm{A} 3$ was identified as 7 (0.5 $\mathrm{mg})$. Fractions $A 7$ and $A 9$ were identified as $5(4.5 \mathrm{mg})$ and $6(6.5 \mathrm{mg})$, respectively. Semi-preparative HPLC (MeCN-0.1\% HCOOH in $\mathrm{H}_{2} \mathrm{O}, 1: 1,3 \mathrm{~mL} / \mathrm{min}$ ) of the pooled fractions $\mathrm{A} 12$ (10.2 mg) and A13 (3.9 $\mathrm{mg}$ ) afforded $2.3 \mathrm{mg}$ of a mixture containing $2\left(\mathrm{R}_{\mathrm{t}}=7.8 \mathrm{~min}\right)$ and $4.7 \mathrm{mg}$ of $1\left(\mathrm{R}_{\mathrm{t}}=9.9 \mathrm{~min}\right)$. Semipreparative $\mathrm{HPLC}$ (MeCN-0.1\% $\mathrm{HCOOH}$ in $\mathrm{H}_{2} \mathrm{O}, 11: 9,3 \mathrm{~mL} / \mathrm{min}$ ) performed on pooled fractions $\mathrm{B}$ (6.8 $\mathrm{mg}$ ) and $\mathrm{C}\left(21.7 \mathrm{mg}\right.$ ) gave $\mathbf{3}\left(7.2 \mathrm{mg}, \mathrm{R}_{\mathrm{t}}=20.4 \mathrm{~min}\right)$ and a fraction containing 4 as a main compound. Finally, the latter fraction $(3.2 \mathrm{mg})$ was pooled with fractions $D(3.1 \mathrm{mg})$ and $A 15(1.4 \mathrm{mg})$ and separated by semi-preparative HPLC ( $\mathrm{MeCN}-0.1 \% \mathrm{HCOOH}$ in $\mathrm{H}_{2} \mathrm{O}, 3: 2,3 \mathrm{~mL} / \mathrm{min}$ ) to yield $4(2.8 \mathrm{mg}$, $\mathrm{R}_{\mathrm{t}}=12.5 \mathrm{~min}$ ).

Procedure B: Isolation of 2 and 3: The entire crude aqueous extract $(27.0 \mathrm{~g})$ was suspended in $\mathrm{H}_{2} \mathrm{O}$ (200 mL) and extracted by $\mathrm{CH}_{2} \mathrm{Cl}_{2}(6 \times 200 \mathrm{~mL})$. Evaporation of the $\mathrm{CH}_{2} \mathrm{Cl}_{2}$ layer under reduced pressure gave rise to $0.62 \mathrm{~g}$ of residue which was chromatographed on SPE C18 cartridge $(10 \mathrm{~g})$ under vacuum ( $\mathrm{P}=5 \mathrm{~mm} \mathrm{Hg}$ ) with $\mathrm{H}_{2} \mathrm{O}$ and increasing amounts of MeCN to give 11 fractions (F1-F11). Fraction F8 (95 $\mathrm{mg}$ ) was chromatographed on a $30 \times 1.5 \mathrm{~cm}$ column, containing silica gel $(10 \mathrm{~g})$ and eluted with $\mathrm{CH}_{2} \mathrm{Cl}_{2}$ with increasing amounts of $\mathrm{MeOH}(0-100 \%)$. This afforded 7 fractions (F81 to F87). Fraction F81 (38 $\mathrm{mg}$ ) was pure and contained 3. Fractions F6 $(185 \mathrm{mg})$ and $\mathrm{F} 7(135 \mathrm{mg})$ were pooled and chromatographed on a $30 \times 1.5 \mathrm{~cm}$ silica gel $(10 \mathrm{~g})$ column eluted with $\mathrm{CH}_{2} \mathrm{Cl}_{2}$ with increasing amounts of $\mathrm{MeOH}$ (0-100 \%) to give 8 fractions (I to VIII). Fraction III (125 mg) was re-chromatographed on the same column and gave 6 sub-fractions (III-1 to III-6). Fraction III-4 was identified as compound 2 (50.8 $\mathrm{mg})$.

\subsection{Biological tests}

\subsubsection{Antileishmanial evaluation}

2.6.1.1. Antileishmanial activity on promastigotes

The effects of the various samples on the growth of promastigotes of Leishmania infantum (MHOM/MA/67/ITMAP-263, CNR Leishmania, Montpellier, France) were assessed using promastigotes expressing luciferase activity. Briefly, promastigotes in log-phase in RPMI 1640 medium supplemented with $10 \%$ foetal calf serum (FCS), $2 \mathrm{mM}$ L-glutamine and antibiotics (100 $\mathrm{U} / \mathrm{mL}$ penicillin, $100 \mu \mathrm{g} / \mathrm{mL}$ streptomycin and $50 \mu \mathrm{g} / \mathrm{mL}$ geneticin), were incubated at an average density of $10^{6}$ parasites $/ \mathrm{mL}$ in sterile 96 -well plates with various concentrations of compounds dissolved in DMSO (final concentration less than $0.5 \% \mathrm{v} / \mathrm{v}$ ), in triplicate. Appropriate controls treated by DMSO and amphotericin $\mathrm{B}$, miltefosine and pentamidine (reference drugs purchased from Sigma Aldrich) were added to each set of experiments. After a $72 \mathrm{~h}$ incubation period at $24^{\circ} \mathrm{C}$, each plate well was microscope-examined to detect the possible formation of precipitate. To estimate the luciferase activity of promastigotes, $80 \mu \mathrm{l}$ of each well were transferred to white 96-well plates, Steady Glow reagent (Promega) was added according to the manufacturer's instructions, and the 
plates were incubated for $2 \mathrm{~min}$. The luminescence was then measured in a Microbeta Luminescence Counter (PerkinElmer). Inhibitory concentration $50 \%\left(\mathrm{IC}_{50}\right)$ was defined as the concentration of drug required to inhibit by $50 \%$ of the metabolic activity of Leishmania infantum promastigotes compared to the control.

\subsubsection{Antileishmanial activity on axenic amastigotes}

L. infantum promastigotes in log phase were centrifuged at $900 \mathrm{~g} 10 \mathrm{~min}$, cell medium was then replaced by MAA-20 medium and maintained at $37^{\circ} \mathrm{C}, 5 \% \mathrm{CO}_{2}$ to induce transformation into axenic amastigote forms (Sereno and Lemesre, 1997). Axenic amastigotes were incubated at an average density of $4.10^{6}$ cells $/ \mathrm{mL}$ in sterile 96 -well plates with various concentrations of compounds dissolved in DMSO (final concentration $1 \% \mathrm{v} / \mathrm{v}$ ), in duplicate. Appropriate controls treated by DMSO and amphotericin $B$, miltefosine and pentamidine were added to each set of experiments. After a $72 \mathrm{~h}$ incubation period at $37^{\circ} \mathrm{C}, 5 \% \mathrm{CO}_{2}$, the effects of the tested compounds were evaluated by estimation of the luciferase activity of the axenic amastigotes. Eighty $\mu$ l of each well were transferred to white 96-well plates, Steady Glow reagent (Promega) was added according to the manufacturer's instructions, and the plates incubated for $2 \mathrm{~min}$. The luminescence was measured in a Microbeta Luminescence Counter (PerkinElmer). Inhibitory concentration $50 \%\left(I C_{50}\right)$ was defined as the concentration of drug required to inhibit $50 \%$ of the metabolic activity of Leishmania infantum amastigotes compared to the control.

\subsubsection{Antileishmanial activity on intramacrophagic amastigotes}

The effects of the compounds tested on the growth of $L$. infantum intracellular amastigotes were assessed in the following way. One hundred $\mu \mathrm{L}$ of J774A.1 cells were seeded in 96-well plates at an average density of $2.10^{5}$ cells $/ \mathrm{mL}$ and incubated for $24 \mathrm{~h}$ at $37{ }^{\circ} \mathrm{C}$ under $5 \% \mathrm{CO}_{2}$. L. Infantum promastigotes were centrifuged at $900 \mathrm{~g}$ for $10 \mathrm{~min}$ and the supernatant replaced by the same volume of RPMI 1640, 10\% FCS, pH 5.4 and incubated for $24 \mathrm{~h}$ at $27^{\circ} \mathrm{C}$. Then, half the macrophage medium was removed, J774A.1 cells were then infected by $100 \mu$ of acidified promastigotes at an average density of $2.10^{6}$ cells $/ \mathrm{mL}\left(10: 1\right.$ ratio) and plates incubated for $24 \mathrm{~h}$ at $37^{\circ} \mathrm{C}$. Half of the infected macrophage medium was removed and medium containing various concentrations of test compounds was added in duplicate. Appropriate controls treated with or without solvent (DMSO), and various concentrations of amphotericin B were added to each set of experiments. After $120 \mathrm{~h}$ incubation at $37^{\circ} \mathrm{C}$ and $5 \% \mathrm{CO}_{2}, 100$ $\mu \mathrm{l}$ of well supernatant was removed and Steady Glow reagent (Promega) was added according to the manufacter's instructions. The plates were incubated for $3 \mathrm{~min}$. Hundred $\mu \mathrm{L}$ of each well were transferred to white 96-well plates and the luminescence was measured in a Microbeta Luminescence Counter (PerkinElmer). Inhibitory concentration $50 \%\left(\mathrm{IC}_{50}\right)$ was defined as the concentration of drug required to inhibit by $50 \%$ the metabolic activity of $L$. Infantum intracellular amastigotes compared to the control. IC $\mathrm{I}_{50}$ were calculated by non-linear regression analysis processed on dose-response curves, using TableCurve $2 \mathrm{D}$ V5 software. $I \mathrm{C}_{50}$ values represent the means calculated from three independent experiments.

\subsubsection{Cytotoxicity evaluation on macrophages and VERO cell lines}

The evaluation of cytotoxicity by MTT assay on the J774A.1 cell line (mouse macrophage cell line, Sigma-Aldrich) and VERO cells (monkey epithelial cell line, Sigma-Aldrich) was done according to Mosmann (Mosmann, 1983) with slight modifications. Briefly, cells $\left(5.10^{4} \mathrm{cells} / \mathrm{mL}\right)$ in $100 \mu \mathrm{L}$ of 
complete medium, [RPMI 1640 supplemented with $10 \%$ foetal calf serum (FCS), 2 mM L-glutamine and antibiotics (100 U/mL penicillin and $100 \mu \mathrm{g} / \mathrm{mL}$ streptomycin) for J774A.1 cell line and MEM with $10 \%$ foetal calf serum (FCS), $2 \mathrm{mM} \mathrm{L-glutamine}$ and antibiotics $(100 \mathrm{U} / \mathrm{mL}$ penicillin and $100 \mu \mathrm{g} / \mathrm{mL}$ streptomycin), NEAA 1X for VERO cell line] were seeded into each well of 96 -well plates and incubated at $37^{\circ} \mathrm{C}, 5 \% \mathrm{CO}_{2}$. After $24 \mathrm{~h}$ incubation, $100 \mu \mathrm{L}$ of medium with various product concentrations and appropriate controls (DMSO and doxorubicin) were added and the plates were incubated for $72 \mathrm{~h}$ at $37^{\circ} \mathrm{C}, 5 \% \mathrm{CO}_{2}$. Each plate well was then microscope-examined to detect possible precipitate formation before the medium was pipetted out of the wells. One hundred $\mu \mathrm{L}$ of MTT solution $(0.5 \mathrm{mg} / \mathrm{mL}$ in RPMI 1640) was then added to each well and the cells incubated $2 \mathrm{~h}$ at $37^{\circ} \mathrm{C}$. After this time, the MTT solution was removed and DMSO (100 $\mathrm{LL} /$ well) was added to dissolve the resulting formazan crystals. Plates were shaken vigorously for $5 \mathrm{~min}$. Absorbance was measured at $570 \mathrm{~nm}$ with a microplate spectrophotometer (EON). Inhibitory concentration $50 \%\left(\mathrm{IC}_{50}\right)$ was defined as the concentration of drug inducing $50 \%$ death of macrophages J774A.1 or VERO cells compared to the control.

\subsubsection{Antiplasmodial evaluation}

The antiplasmodial activity was assessed on the chloroquine-resistant Plasmodium falciparum strain FcM29-Cameroon, cultured continuously according to the method of Trager and Jensen (Trager and Jensen, 1976), in a $5 \% \mathrm{CO}_{2}$ atmosphere at $37^{\circ} \mathrm{C}$ as previously described (Benoit-Vical et al., 2007). Briefly, the parasites were maintained in vitro in human red blood cells and diluted in RPMI 1640 medium, supplemented with $25 \mathrm{mM}$ HEPES, $2.05 \mathrm{mM}$ L-glutamine and completed with $5 \%$ human serum (French Blood Bank, EFS). The antiplasmodial activity was assessed as previously reported by Desjardins et al. (Desjardins et al., 1979) and modified as follows. Extract dilutions and compounds were tested 3 times independently, each dilution in triplicate, in 96-well plates with cultures at a parasitaemia of $1 \%$ and a haematocrit of $1 \%$. For each test, the plates of parasite culture were incubated with products for $48 \mathrm{~h}$ and tritiated hypoxanthine (Perkin Elmer, France) was added to the medium $24 \mathrm{~h}$ after the beginning of incubation (Benoit-Vical et al., 2007). The parasite culture control (with solvent only) was referred to as $100 \%$ growth. Parasite growth was estimated by $\left[{ }^{3} \mathrm{H}\right]-$ hypoxanthine incorporation. Inhibitory concentration $50 \%\left(\mathrm{IC}_{50}\right)$ was defined as the concentration of drug required to inhibit $50 \%$ of the metabolic activity of Plasmodium falciparum compared to the control.

\subsection{4. $I C_{50}, C C_{50}$ and selectivity index (SI) calculation}

$\mathrm{IC}_{50}$ on L. infantum and $\mathrm{CC}_{50}$ on macrophages and VERO cells were calculated by non-linear regression analysis processed on dose-response curves, using Table Curve 2D V5 software. IC $\mathrm{C}_{50}$ values represent the mean value calculated from three independent experiments. Results were expressed as means followed by standard deviation. The selectivity index (SI) value allowed the comparison of the toxicity of the extracts or compounds against normal cells compared to the activity against the parasites in order to assess of their selectivity as antiparasitic. The SI on L. infantum was calculated as the ratio between the $\mathrm{CC}_{50}$ values against macrophages and $\mathrm{IC}_{50}$ values against promastigote forms. The $\mathrm{SI}$ on $P$. falciparum was calculated as the ratio between the $\mathrm{CC}_{50}$ values against VERO cells and $\mathrm{IC}_{50}$ values against $P$.falciparum. In both cases, $\mathrm{SI}=\mathrm{CC}_{50} / \mathrm{IC}_{50}$. 


\section{Results}

\subsection{Structural elucidation of isolated compounds by NMR analysis}

Hirsutinolides 1 to 7 (Fig. 1) were clearly identified mainly on the basis of their $1 \mathrm{D}\left({ }^{1} \mathrm{H}-{ }^{13} \mathrm{C}-\mathrm{NMR}\right)$ and 2D ( $\mathrm{HSQC}$ and $\mathrm{HMBC}$ ) NMR parameters, in $\mathrm{CDCl}_{3}$. They were compared with NMR data published in the literature in the same solvent. This permitted the identification of 8-acetyl-13ethoxypiptocarphol (1) ((Catalán et al., 1986), corrected in (Catalán et al., 1988)), diacetylpiptocarphol (2) ((Catalán et al., 1986), corrected in (Bardón et al., 1993)), piptocarphin A (3), piptocarphin F (4), piptocarphin D (5) ((Cowall et al., 1981), corrected in (Catalán et al., 1988)), $\left(1 \mathrm{~S}^{*}, 4 \mathrm{R}^{*}, 8 \mathrm{~S}^{*}, 10 \mathrm{R}^{*}\right)$-1,4-epoxy-13-ethoxy-1,8,10-trihydroxygermacra-5E,7(11)-dien-6, 12-olide (6) (Kotowicz et al., 1998), and piptocarphol (7) (Bardón et al., 1993). In the course of our search for the improvement of NMR spectra of some hirsutinolides presenting enlargements of ${ }^{1} \mathrm{H}$-NMR signals (Fig. S2 supplementary data), NMR analyses were run in $\mathrm{CD}_{3} \mathrm{OD}$ while $\mathrm{CDCl}_{3}$ and $\mathrm{C}_{6} \mathrm{D}_{6}$ were generally the solvents prevailing in the literature (Bardón et al., 1993; Catalán et al., 1988; Kotowicz et al., 1998). In such conditions, it appeared that C-8 hydroxylated compounds 5-7 exhibited peaks distinctly split while a unique form remained in $\mathrm{CDCl}_{3}$ for these three compounds (Fig. S6 to S19 in Supplementary data). As far as we know, this is the first time that such a phenomenon has been described for hirsutinolides. Heteronuclear $2 \mathrm{D}$ NMR experiments $\mathrm{HSQC}$ and $\mathrm{HMBC}$ recorded in $\mathrm{CD}_{3} \mathrm{OD}$ confirmed the existence of two forms of the same compound. The fact that a unique form is present in $\mathrm{CDCl}_{3}$, even after a previous analysis in $\mathrm{CD}_{3} \mathrm{OD}$, suggests the reversibility of the reaction, and the involvement of the deuterated NMR solvents. Moreover, compounds 5-7 were analysed by UHPLCMS under acidic conditions, and two main peaks displaying the same mass appeared in the chromatograms confirming the presence of two forms. It is worth noting that this phenomenon only appeared for the C-8 hydroxylated derivatives 5-7. For C-8 esterified analogues 1-4, only one form appeared whatever conditions suggesting the involvement of the hydroxyl function in a hydrogen bond. ${ }^{1} \mathrm{H}$ NMR spectra of compounds 5-7 recorded in $\mathrm{CDCl}_{3}$ exhibited a doublet signal close to $\delta 6$ ppm with a coupling constant of $J=12 \mathrm{~Hz}$ corresponding to the non-exchangeable hydroxyl proton 8$\mathrm{OH}$ coupled with H-8 close to $5.5 \mathrm{ppm}$. Therefore, the NMR signal of $\mathrm{H}-8$ was a ddd $\left(\mathrm{J}_{8 / 9 \mathrm{a}}=11 \mathrm{~Hz}, \mathrm{~J}_{8 / 9 \mathrm{~b}}=\right.$ $\left.2 \mathrm{~Hz}, J_{8 / 8-\mathrm{OH}}=12 \mathrm{~Hz}\right)$, or appeared as a doublet of doublets $\left(J_{8 / 9 \mathrm{a}}=11 \mathrm{~Hz}, J_{8 / 8-\mathrm{OH}}=12 \mathrm{~Hz}\right)$ given the low value of the $J_{8 / 9 b}$ coupling constant. This large coupling constant suggests the presence of an intramolecular hydrogen bond occurring between the 8-OH and most likely the ether bridge oxygen as suggested before for a similar hirsutinolide (Yang et al., 2007). Borkosky and colleagues isolated a hirsutinolide structurally similar to $\mathbf{5}$ (referred as compound $7 \mathrm{f}$ in their publication)(Borkosky et al., 1997). The NMR signal of $\mathrm{H}-8$ for this compound, in $\mathrm{CDCl}_{3}$, appeared as a doublet of doublets $\left(J_{8 / 9 \mathrm{a}}=2\right.$ $\mathrm{Hz}$ and $J_{8 / 9 b}=6 \mathrm{~Hz}$ ) indicating no intramolecular hydrogen bond. The only differences between compound $\mathbf{5}$ and the hirstunolide described by Borkosky and collaborators were the absence of a hydroxyl at $\mathrm{C}-10$ and the $\alpha$-orientation of the methyl at $\mathrm{C}-10$. Moreover, it can be noted that a unique conformer was described for other C-8 hydroxylated hirsutinolides with an $\alpha$-oriented C-10 methyl when NMR analyses were recorded in $\mathrm{CD}_{3} \mathrm{OD}$ (Youn et al., 2012). This suggests that the presence of hydroxyl groups at C-8 and C-10 was responsible for the intramolecular bond occurring in compounds 5-7. Jakupovic and colleagues reported that the quaternization of carbon 10 by an oxygenated group in hirsutinolides led to the $\beta$-orientation of the methyl group at C-10 (Jakupovic et al., 1985). From this assumption, the $\mathrm{H}$-bond may occur between $8-\mathrm{OH}$ and $10-\mathrm{OH}$ or with the oxygen of the ether bridge because of a conformational change induced by the presence of the $\alpha$-oriented hydroxyl 
group at $\mathrm{C}-10$. Our hypothesis is therefore that this hydrogen bond is partially disrupted by $\mathrm{CD}_{3} \mathrm{OD}$, a polar protic solvent, and led to a mixture of two conformers.

\subsection{Biological activities}

\subsubsection{Antiplasmodial, antileishmanial and cytotoxicity properties of ethanolic and aqueous extracts of $P$. spiralis}

The antiplasmodial activities against $P$. falciparum of extracts obtained from the leaves of $P$. spiralis are displayed in Table 1. The aqueous extract exhibited the highest antiplasmodial activity with an $I_{50}$ value of $3.0 \mu \mathrm{g} / \mathrm{mL}$. This corresponds to a good activity according to the standard antiplasmodial score (Willcox et al., 2011). The ethanolic extract with an $\mathrm{IC}_{50}$ of $21.1 \mu \mathrm{g} / \mathrm{mL}$, showed a low activity. The cytoxicity was evaluated on mammalian VERO cell lines. Both extracts displayed high cytotoxicity against this healthy cell line with median cytotoxicity concentrations of 1.7 and $2.5 \mu \mathrm{g} / \mathrm{mL}$ for aqueous and ethanolic extracts, respectively.

Both extracts were also tested against the promastigote stage of Leishmania infantum (Table 1). The aqueous extract was the more active with a good efficacy, the $I C_{50}$ value $\left(I C_{50}=13.4 \mu \mathrm{g} / \mathrm{mL}\right)$ being between 10 and $50 \mu \mathrm{g} / \mathrm{mL}$ (Osorio et al., 2007) while the ethanolic extract was inactive $\left(I C_{50}>50\right.$ $\mu \mathrm{g} / \mathrm{mL}$ ). The cytotoxicities of extracts were also assessed on macrophages as they are the host cells of Leishmania. The aqueous extract was shown to be cytotoxic with a selectivity index of less than 1 .

\subsubsection{Biological activities of isolated compounds}

The in vitro antileishmanial and antiplasmodial activities of isolated sesquiterpene lactones $\mathbf{2}, \mathbf{3}, \mathbf{5}, \mathbf{6}$ and $\mathbf{7}$ are presented in Table 1. Compounds $\mathbf{1}$ and $\mathbf{4}$ could not be tested because of their instability.

\subsubsection{Antiplasmodial activity and cytotoxicity of isolated compounds}

The sesquiterpene lactones $\mathbf{2}$ and $\mathbf{3}$ were the most active compounds with $\mathrm{IC}_{50}$ values of $7.8 \mu \mathrm{M}$ and $6.9 \mu \mathrm{M}$, respectively. Compounds 5 and 6 were inactive against the parasite $\left(I_{5_{0}}>50 \mu \mathrm{M}\right)$ and $\mathbf{7}$ could not be tested against malaria because of its rapid degradation. In parallel, it appeared that $\mathbf{2}$ and $\mathbf{3}$ were strongly cytotoxic towards VERO cells with $\mathrm{CC}_{50}$ values of 3.7 and $1.8 \mu \mathrm{M}$, respectively. Although compound 5 was less cytotoxic $\left(C_{50}=17.6 \mu \mathrm{M}\right)$ than $\mathbf{2}$ or $\mathbf{3}$, its antiplasmodial activity was still not selective. Compounds $6\left(\mathrm{CC}_{50}=75.2 \mu \mathrm{M}\right)$ and $7\left(\mathrm{CC}_{50}=90 \mu \mathrm{M}\right)$ exhibited no cytotoxicity.

\subsubsection{Antileishmanial activity and cytotoxicity on macrophages of isolated} compounds

Compounds 2, 3, 5, $\mathbf{6}$ and $\mathbf{7}$ were tested against the promastigote and axenic amastigote stages of $L$. infantum. Generally, all the tested compounds are more active against the amastigote stage than the promastigote form of the parasite. Hirsutinolide $\mathbf{3}$ displayed the strongest activity against the promastigotes and axenic amastigotes of $L$. infantum with $\mathrm{IC}_{50}$ values of 9.5 and $2.0 \mu \mathrm{M}$ respectively. Note that the $\mathrm{IC}_{50}$ of $9.5 \mu \mathrm{M}$ against promastigotes is close to that of the reference miltefosine (8.8 $\mu \mathrm{M})$. Concerning the activities of the other compounds against the two stages of the parasite, they can be ranked by decreasing the order of efficiency: $2>6>5>7,7$ being totally inactive against $L$. infantum. Concerning their cytotoxicity towards macrophages, the most interesting compound, $\mathbf{3}$, 
appeared much more cytotoxic than miltefosine with $\mathrm{CC}_{50}$ values of 0.9 and $155.3 \mu \mathrm{M}$, respectively. The other products $\mathbf{2}, \mathbf{3}, \mathbf{5}$ and $\mathbf{6}$ also exhibited strong cytotoxicities with $\mathrm{CC}_{50}$ between 1.4 and 5.5 $\mu \mathrm{M}$. Compounds 2, 3, 5 and $\mathbf{6}$ were also tested on intramacrophagic amastigotes of $L$. infantum, and all compounds were found to be inactive at concentrations lower than their $\mathrm{CC}_{50}$ on macrophages.

\section{Discussion}

\subsection{Structural identification}

One of the main problems encountered during the identification of the compounds isolated in this work concerned the C-8 hydroxylated hirsutinolides $\mathbf{5}$ to $\mathbf{7}$ that exhibited two conformers when NMR analyses were recorded in $\mathrm{CD}_{3} \mathrm{OD}$. The hard process of NMR structural elucidation of hirsutinolides has long baffled researchers who have faced it. Indeed, the complex structural core of these germacrane-type sesquiterpene lactones and the presence of four chiral carbons have generated various representations in the plan of their formula in the literature. Consequently, this led to confusions about their stereochemistry (Catalán et al., 1988), finally resolved by the rigorous application of the conventional representation rules published by Rogers et al. for germacranolide sesquiterpenes (Rogers et al., 1972). Moreover, due to the conformational flexibility of the 10membered ring, the NMR spectra of hirsutinolides exhibited peak enlargement implying poorly resolved signals, attributed to the existence of several conformers in equilibrium. Analyses often have to be recorded at high temperature in $\mathrm{C}_{6} \mathrm{D}_{6}$ to limit the broadening of peaks, even so several of the signals remained broad leading to difficulties in structural elucidation (Bardón et al., 1993, 1992). This along with the high number of quaternary carbons in the structure precludes drawing inferences about stereochemistry from NOE (Catalán et al., 1988). The stereochemical determination of hirsutinolides was thus strewed with a number of missassignments over the years regarding the chiral positions at C-8 (Catalán et al., 1988) and C-10 (Cowall et al., 1981; Herz and Kulanthaivel, 1983; Jakupovic et al., 1985). Those errors were partially resolved thanks to X-ray analysis made possible for $8 \alpha$-angeloyloxyhirsutinolide 13-O-acetate (Catalán et al., 1988; Jakupovic et al., 1985). However, some uncertainties still remain for various molecules of the family (Bardón et al., 1988; Pollora et al., 2000). In this work, the configuration was established by hypothesizing and comparing the chemical shifts and the coupling constants of the compounds. Knowing that two conformers coexist in $\mathrm{CD}_{3} \mathrm{OD}$ solutions of $\mathrm{C}-8$ hydroxylated hirsutinolides facilitates the understanding of complex NMR and HPLC data, making their isolation easier and avoiding errors in their identification. Isolated compound 7 has been described before as an isomeric mixture of $8 \alpha$ and $8 \beta$ diastereoisomers (Issa et al., 2006). The $8 S^{*}$ configuration appears to be generally accepted now concerning all hirsutinolides, i.e. with $\mathrm{H}-8$ in the $\beta$ position (Catalán et al., 1988; Jakupovic et al., 1985). There have been no reports as far as we know about an $8 \mathrm{R}^{*}$ configuration of such compounds in the literature (except early reports that have since been revised (Bohlmann et al., 1979, 1978; Catalán et al., 1986; Cowall et al., 1981)). In this context, it is fully justified to have doubts about the stereochemistry described for $\alpha-\mathrm{H}-8$ piptocarphol by Issa and colleagues (referred to as compound 4 in their publication) (Issa et al., 2006). In their article, the NMR data of the two isomers were not actually published but it can be suggested that there are in fact two conformers, as some of the NMR analyses seemed to be carried out in $\mathrm{CD}_{3} \mathrm{OD}$. This kind of phenomenon might also occur for other germacranolides exhibiting an ether bridge spatially close to a hydroxyl function. 


\subsection{Biological analysis}

The results showed that the traditional preparation (aqueous extract) of $P$. spiralis, exhibited a good antiplasmodial activity against $P$. falciparum whereas the ethanolic extract was only weakly active. This result validates the traditional use of this herb in the treatment of malaria or associated symptoms in South America. Concerning the antileishmanial activity against L. infantum, while the ethanolic extract was inactive, the aqueous extract again presented a good activity. From the seven hirsutinolide-type sesquiterpene lactones isolated from $P$. spiralis, five were tested for their antiprotozoal activities. Compounds $\mathbf{2}$ and $\mathbf{3}$ were the most active molecules against both parasites but also the most toxic on both VERO cells and macrophages. Furthermore, they had no effect on intramacrophagic amastigotes at concentrations non-toxic for the macrophage. Numerous sesquiterpene lactones are known to be bioactive as they interact through Michael type additions with various nucleophilic biological targets (Ghantous et al., 2010; Kupchan et al., 1971; Merfort, 2011; Schmidt, 2006). This confers them a large spectrum of biological activities, including antiplasmodial and antileishmanial activities (Lavault et al., 2005; Tiuman et al., 2005; Toyang et al., 2013) also reported for hirsutinolides (Chea et al., 2006; Odonne et al., 2011; Pillay et al., 2007). It has been suggested by Pillay and colleagues that the antiplasmodial activity of hirsutinolides is due to their $2(5 \mathrm{H})$ furanone moiety (Pillay et al., 2007). More generally, Schmidt and co-workers demonstrated that the $\alpha, \beta$-unsaturated carbonyl moiety was the key pharmacophore, not only for antiprotozoal activity, but also for the cytotoxic properties of sesquiterpene lactones (Schmidt, 2006; Schmidt et al., 2009). Thereby, it is not surprising that compound $\mathbf{3}$, the only compound tested here displaying a methacrylate ester in its structure, was also the most active molecule. Hirsutinolides $\mathbf{5}$ to 7, with a free $\mathrm{OH}$ on $\mathrm{C}-8$, were found to be the least active compounds suggesting that the etherification of this hydroxyl group is important for activity and cytotoxicity. Two of the isolated hirsutinolides ( $\mathbf{1}$ and $\mathbf{2}$ ) have already been isolated before from the traditional antileishmanial herb Pseudelephantopus spicatus, and tested for their in vitro antileishmanial activities against axenic amastigotes of Leishmania amazonensis, one of the cutaneous Leishmaniasis species. Both were reported to be strongly active with $\mathrm{IC}_{50}$ values of $0.37 \mu \mathrm{M}(\mathbf{1})$ and $0.20 \mu \mathrm{M}(2)$, close to the activity displayed by Amphotericin $\mathrm{B}\left(\mathrm{IC}_{50}=0.41 \mu \mathrm{M}\right)$. Hirsutinolide 1 was not tested by our team but the activity of compound 2 against amastigotes of $L$. infantum $\left(\mathrm{IC}_{50}=4.7 \mu \mathrm{M}\right)$ appeared to be more than 20 times less than against amastigotes of $L$. amazonensis. This could be explained by inter-species Leishmania variability regarding to the efficacy of different drugs (Croft et al., 2006; Morais-Teixeira et al., 2011). Cytotoxicity towards host cells is a very important criterion for assessing the selectivity of the pharmacological activities observed. Given the strong activity against L. amazonensis displayed by $\mathbf{2}$ and its absence of cytotoxicity on various tumoral mammalian cell lines reported in the literature (Buskuhl et al., 2010), Odonne et al. reported it to be a good antileishmanial agent. However, considering the poor selectivity of $\mathbf{2}$ with respect to macrophages, and its lack of activity on intramacrophagic amastigotes in the present work, the antileishmanial potential of this compound would appear to require reassessment.

Despite the good antiprotozoal activity displayed by the aqueous extract of $P$. spiralis and isolated compounds $\mathbf{2}$ and $\mathbf{3}$, probably responsible for the extract's efficacy, their cytotoxicity underlined in this study appeared to be critical. Furthermore, aqueous extracts and all the individual compounds tested were found to be cytotoxic to macrophages. As bioactive compounds, hirsutinolides have already been pointed out as potent inhibitors of various tumoral cell lines. Buskuhl and colleagues even warned about the potential genotoxicity of compounds 1 and 2 (Buskuhl et al., 2010). In the 
light of these results and in order to assess the real safety of $P$. spiralis preparations in folk medicine, it appeared advisable to carry out further toxicological evaluations, particularly in vivo assays. A suitable method for the determination of the most cytotoxic compounds, $\mathbf{2}$ and $\mathbf{3}$, in the traditional preparation is also required as they represent $0.3 \%(\mathrm{w} / \mathrm{w})$ of the aqueous extract. Moreover, owing to the lack of selectivity of both aqueous extract and individual hirsutinolides against Leishmania infantum, an assessment of the safety of the traditional antileishmanial remedy obtained from $P$. spicatus seems to be necessary as previously proposed by Odonne and coworkers (Odonne et al., 2011).

\section{Conclusion}

The in-vitro antiplasmodial activity of aqueous extract and of its purified main compounds $\mathbf{2}$ and $\mathbf{3}$ from Pseudelephantopus spiralis may underlie the use of this plant in South American folk medicine to treat malaria. So far, no work has been reported as to the phytochemical composition of this traditional remedy and $P$. spiralis extracts had not been tested in vitro for potential antiplasmodial and antileishmanial activities. In addition, because of the toxicity of the active components of the aqueous extract, diacetylpiptocarphol (2) and piptocarphin A (3), against healthy cell lines and macrophages, further studies are needed to assess the safety of the traditional preparation in in-vivo animal models. It also appears advisable to develop an analytical method for the quantification of diacetylpiptocarphol (2) and piptocarphin A (3) in the traditional P. spiralis preparation.

\section{Supporting information}

\section{Acknowledgements}

This work was performed in the framework of a collaborative and hosting agreement signed between CNRS, IRD and UPS-Toulouse. The authors are grateful to Pierre Lavedan, Marc Vedrenne and Caroline Toppan from the NMR platform of the Institut de Chimie de Toulouse (ICT) for NMR analyses. The French Ministry of Higher Education and Research is greatly acknowledged for financial support (PhD grant).

\section{References}

Bardón, A., Catalán, C.A.N., Gutiérrez, A.B., Herz, W., 1988. Piptocarphol esters and other constituents from Vernonia cognata. Phytochemistry 27, 2989-2990. doi:10.1016/00319422(88)80706-4

Bardón, A., Kamiya, N.I., De Ponce De Léon, C.A., Catalán, C.A.N., Díaz, J.G., Herz, W., 1992. Glaucolides and related sesquiterpene lactones from Vernonia nudiflora and Chrysolaena propinqua. Phytochemistry 31, 609-613. doi:10.1016/0031-9422(92)90045-R

Bardón, A., Montanaro, S., Catalán, C.A.N., Diaz, J.G., Herz, W., 1993. Piptocarphols and other constituents of Chrysolaena verbascifolia and Lessingianthus rubricaulis. Phytochemistry 34, 253259.

Benoit-Vical, F., Lelièvre, J., Berry, A., Deymier, C., Dechy-Cabaret, O., Cazelles, J., Loup, C., Robert, A., Magnaval, J.-F., Meunier, B., 2007. Trioxaquines are new antimalarial agents active on all erythrocytic forms, including gametocytes. Antimicrob. Agents Chemother. 51, 1463-1472.

doi:10.1128/AAC.00967-06 
Blair Trujillo, S., Madrigal, B., 2005. Plantas antimalaricas de Tumaco: costa pacifica colombiana. Universidad de Antioquia, Medellín.

Bohlmann, F., Brindöpke, G., Rastogi, R.C., 1978. A new type of germacranolide from Vernonia species. Phytochemistry 17, 475-482. doi:10.1016/S0031-9422(00)89342-5

Bohlmann, F., Mahanta, P.K., Dutta, L.N., 1979. Weitere hirsutinolide aus Vernonia-arten. Phytochemistry 18, 289-291. doi:10.1016/0031-9422(79)80073-4

Borkosky, S., Bardón, A., Catalán, C.A.N., Díaz, J.G., Herz, W., 1997. Glaucolides, hirsutinolides and other sesquiterpene lactones from Vernonanthura pinguis. Phytochemistry 44, 465-470. doi:10.1016/S0031-9422(96)00481-5

Buskuhl, H., de Oliveira, F.L., Blind, L.Z., de Freitas, R.A., Barison, A., Campos, F.R., Corilo, Y.E., Eberlin, M.N., Caramori, G.F., Biavatti, M.W., 2010. Sesquiterpene lactones from Vernonia scorpioides and their in vitro cytotoxicity. Phytochemistry 71, 1539-1544. doi:10.1016/j.phytochem.2010.06.007

Bussmann, R.W., Sharon, D., 2006. Traditional medicinal plant use in Loja province, Southern Ecuador. J. Ethnobiol. Ethnomedicine 2, 44. doi:10.1186/1746-4269-2-44

Canizales, S.A., Celemín, J.S., Mora-Delgado, J., 2010. Diversidad y uso de arvenses en pasturas de fincas ganaderas del Alto Magdalena (Tolima, Colombia). Zootec. Trop. 28, 427-437.

Catalán, C.A.N., De Iglesias, D.I.A., Kavka, J., Sosa, V.E., Herz, W., 1988. Glaucolides and related sesquiterpene lactones from Vernonia chamaedrys. Phytochemistry 27, 197-202. doi:10.1016/00319422(88)80613-7

Catalán, C.A.N., De Iglesias, D.I.A., Kavka, J., Sosa, V.E., Herz, W., 1986. Sesquiterpene lactones and other constituents of Vernonia mollissima and Vernonia squamulosa. J. Nat. Prod. 49, 351-353.

Chea, A., Hout, S., Long, C., Marcourt, L., Faure, R., Azas, N., Elias, R., 2006. Antimalarial activity of sesquiterpene lactones from Vernonia cinerea. Chem. Pharm. Bull. (Tokyo) 54, 1437-1439.

Cowall, P., Cassady, J.M., Chang, C.-J., Kozlowski, J.F., 1981. Isolation and structure determination of piptocarphins A-F, cytotoxic germacranolide lactones from Piptocarpha chontalensis. J. Org. Chem. 46, 1108-1114. doi:10.1021/jo00319a014

Cragg, G.M., Newman, D.J., 2013. Natural products: A continuing source of novel drug leads. Biochim. Biophys. Acta BBA - Gen. Subj. 1830, 3670-3695. doi:10.1016/j.bbagen.2013.02.008

Croft, S.L., Sundar, S., Fairlamb, A.H., 2006. Drug resistance in leishmaniasis. Clin. Microbiol. Rev. 19, 111-126. doi:10.1128/CMR.19.1.111-126.2006

Desjardins, R.E., Canfield, C.J., Haynes, J.D., Chulay, J.D., 1979. Quantitative assessment of antimalarial activity in vitro by a semiautomated microdilution technique. Antimicrob. Agents Chemother. 16, 710-718. doi:10.1128/AAC.16.6.710

Domingues Passero, L.F., Laurenti, M.D., Santos-Gomes, G., Soares Campos, B.L., Sartorelli, P., Lago, G., Henrique, J., 2014. Plants used in traditional medicine: extracts and secondary metabolites exhibiting antileishmanial activity. Curr. Clin. Pharmacol. 9, 187-204. 
Fournet, A., Munoz, V., 2002. Natural products as trypanocidal, antileishmanial and antimalarial drugs. Curr. Top. Med. Chem. 2, 1215-1237. doi:10.2174/1568026023393011

Ghantous, A., Gali-Muhtasib, H., Vuorela, H., Saliba, N.A., Darwiche, N., 2010. What made sesquiterpene lactones reach cancer clinical trials? Drug Discov. Today 15, 668-678.

doi:10.1016/j.drudis.2010.06.002

Herz, W., Kulanthaivel, P., 1983. Piptocarphol esters from Piptocarpha opaca. Phytochemistry 22, 1286-1287. doi:10.1016/0031-9422(83)80245-3

Internal report: base de datos de las plantas medicinales. 2010. IIAP [WWW Document], n.d. . Scribd. URL http://www.scribd.com/doc/219478120/Base-de-Datos-de-Las-Plantas-Medicinales-2010-IIAP (accessed 4.24.14).

Issa, H.H., Chang, S.M., Yang, Y.L., Chang, F.R., Wu, Y.C., 2006. New sesquiterpene lactones from the aerial parts of Pseudoelephantopus spicatus. Chem. Pharm. Bull. (Tokyo) 54, 1599-1601.

Jakupovic, J., Schmeda-hirschmann, G., Schuster, A., Zdero, C., Bohlmann, F., King, R.M., Robinson, H., Pickardt, J., 1985. Hirsutinolides, glaucolides and sesquiterpene lactone from Vernonia species. Phytochemistry 25, 145-158. doi:10.1016/S0031-9422(00)94520-5

Kotowicz, C., Bardón, A., Catalán, C.A.N., Cerda-García-Rojas, C.M., Joseph-Nathan, P., 1998. Glaucolides and hirsutinolides from Vernonanthura squamulosa. Phytochemistry 47, 425-428.

Kupchan, S.M., Eakin, M.A., Thomas, A.M., 1971. Tumor inhibitors. 69. Structure-cytotoxicity relationships among the sesquiterpene lactones. J. Med. Chem. 14, 1147-1152.

Kvist, L.P., Christensen, S.B., Rasmussen, H.B., Mejia, K., Gonzalez, A., 2006. Identification and evaluation of Peruvian plants used to treat malaria and leishmaniasis. J. Ethnopharmacol. 106, 390402. doi:10.1016/j.jep.2006.01.020

Lavault, M., Landreau, A., Larcher, G., Bouchara, J.-P., Pagniez, F., Le Pape, P., Richomme, P., 2005. Antileishmanial and antifungal activities of xanthanolides isolated from Xanthium macrocarpum. Fitoterapia 76, 363-366. doi:10.1016/j.fitote.2005.03.019

Macbride, J.F., 1936. Flora of Peru. Chicago, U.S.A. : Field Museum of Natural History.

Merfort, I., 2011. Perspectives on sesquiterpene lactones in inflammation and cancer. Curr. Drug Targets 12, 1560-1573.

Morais-Teixeira, E. de, Damasceno, Q.S., Galuppo, M.K., Romanha, A.J., Rabello, A., 2011. The in vitro leishmanicidal activity of hexadecylphosphocholine (miltefosine) against four medically relevant Leishmania species of Brazil. Mem. Inst. Oswaldo Cruz 106, 475-478. doi:10.1590/S007402762011000400015

Mosmann, T., 1983. Rapid colorimetric assay for cellular growth and survival: application to proliferation and cytotoxicity assays. J. Immunol. Methods 65, 55-63.

Ochoa, J.G., Andrade, G.I., 2003. The introduced flora to Machu Picchu sanctuary: an inventory and management priorities for biodiversity conservation. Ecol. En Boliv. 38, 141. 
Odonne, G., Herbette, G., Eparvier, V., Bourdy, G., Rojas, R., Sauvain, M., Stien, D., 2011.

Antileishmanial sesquiterpene lactones from Pseudelephantopus spicatus, a traditional remedy from the Chayahuita Amerindians (Peru). Part III. J. Ethnopharmacol. 137, 875-879.

doi:10.1016/j.jep.2011.07.008

Odonne, G., Valadeau, C., Alban-Castillo, J., Stien, D., Sauvain, M., Bourdy, G., 2013. Medical ethnobotany of the Chayahuita of the Paranapura basin (peruvian amazon). J. Ethnopharmacol. 146, 127-153. doi:10.1016/j.jep.2012.12.014

Osorio, E., Arango, G.J., Jiménez, N., Alzate, F., Ruiz, G., Gutiérrez, D., Paco, M.A., Giménez, A., Robledo, S., 2007. Antiprotozoal and cytotoxic activities in vitro of colombian Annonaceae. J. Ethnopharmacol. 111, 630-635. doi:10.1016/j.jep.2007.01.015

Pillay, P., Vleggaar, R., Maharaj, V.J., Smith, P.J., Lategan, C.A., Chouteau, F., Chibale, K., 2007. Antiplasmodial hirsutinolides from Vernonia staehelinoides and their utilization towards a simplified pharmacophore. Phytochemistry 68, 1200-1205. doi:10.1016/j.phytochem.2007.02.019

Pollora, G.C., Bardón, A., Catalán, C.A., Gedris, T.E., Herz, W., 2000. Sesquiterpene lactones from Chrysolaena platensis. Biochem. Syst. Ecol. 28, 707-711.

Pruski, J.F., 2011. Asteraceae, in: Flora Mesoamericana. Missouri Botanical Garden Press, pp. 608625.

Rogers, D., Moss, G.P., Neidle, S., 1972. Proposed conventions for describing germacranolide sesquiterpenes. J. Chem. Soc. Chem. Commun. 142. doi:10.1039/c39720000142

Romero, G.A.S., Boelaert, M., 2010. Control of visceral leishmaniasis in Latin America-a systematic review. PLoS NegI Trop Dis 4, e584. doi:10.1371/journal.pntd.0000584

Schmidt, T.J., 2006. Structure-activity relationships of sesquiterpene lactones, in: Atta-ur Rahman (Ed.), Studies in Natural Products Chemistry, Bioactive Natural Products (Part M). Elsevier, pp. 309392.

Schmidt, T.J., Khalid, S.A., Romanha, A.J., Alves, T.M.A., Biavatti, M.W., Brun, R., Da Costa, F.B., De Castro, S.L., Ferreira, V.F., De Lacerda, M.V.G., others, 2012a. The potential of secondary metabolites from plants as drugs or leads against protozoan neglected diseases-Part II. Curr Med Chem 19, 21762228.

Schmidt, T.J., Khalid, S.A., Romanha, A.J., Alves, T.M., Biavatti, M.W., Brun, R., Da Costa, F.B., de Castro, S.L., Ferreira, V.F., de Lacerda, M.V., others, 2012b. The potential of secondary metabolites from plants as drugs or leads against protozoan neglected diseases-part I. Curr Med Chem 19, 2128-2175.

Schmidt, T.J., Nour, A.M.M., Khalid, S.A., Kaiser, M., Brun, R., 2009. Quantitative structureantiprotozoal activityrelationships of sesquiterpene lactones. Mol. Basel Switz. 14, 2062-2076. doi:10.3390/molecules14062062

Sereno, D., Lemesre, J.L., 1997. Axenically cultured amastigote forms as an in vitro model for investigation of antileishmanial agents. Antimicrob. Agents Chemother. 41, 972-976. 
Singh, N., Mishra, B.B., Bajpai, S., Singh, R.K., Tiwari, V.K., 2014. Natural product based leads to fight against leishmaniasis. Bioorg. Med. Chem. 22, 18-45. doi:10.1016/j.bmc.2013.11.048

Tiuman, T.S., Ueda-Nakamura, T., Garcia Cortez, D.A., Dias Filho, B.P., Morgado-Díaz, J.A., de Souza, W., Nakamura, C.V., 2005. Antileishmanial activity of parthenolide, a sesquiterpene lactone isolated from Tanacetum parthenium. Antimicrob. Agents Chemother. 49, 176-182.

doi:10.1128/AAC.49.11.176-182.2005

Toyang, N.J., Krause, M.A., Fairhurst, R.M., Tane, P., Bryant, J., Verpoorte, R., 2013. Antiplasmodial activity of sesquiterpene lactones and a sucrose ester from Vernonia guineensis Benth. (Asteraceae). J. Ethnopharmacol. 147, 618-621. doi:10.1016/j.jep.2013.03.051

Trager, W., Jensen, J.B., 1976. Human malaria parasites in continuous culture. Science 193, 673-675.

Tye, A., 2001. Invasive plant problems and requirements for weed risk assessment in the Galapagos Islands, in: Weed Risk Assessment. Csiro Publishing, pp. 153-175.

Valadeau, C., Pabon, A., Deharo, E., Albán-Castillo, J., Estevez, Y., Lores, F.A., Rojas, R., Gamboa, D., Sauvain, M., Castillo, D., Bourdy, G., 2009. Medicinal plants from the Yanesha (Peru): evaluation of the leishmanicidal and antimalarial activity of selected extracts. J. Ethnopharmacol. 123, 413-422.

WHO | Leishmaniasis Fact sheet $\mathrm{N}^{\circ} 375$ [WWW Document], n.d. . WHO. URL

http://www.who.int/mediacentre/factsheets/fs375/en/ (accessed 12.16.14).

WHO | Malaria Fact sheet $\mathrm{N}^{\circ} 94$ [WWW Document], n.d. . WHO. URL http://www.who.int/mediacentre/factsheets/fs094/en/ (accessed 12.16.14).

WHO Expert Committee on the Control of the Leishmaniases, Meeting, W.H.O. (Eds.), 2010. Control of the leishmaniases: report of a meeting of the WHO expert committee on the control of leishmaniases, Geneva, 22-26 March 2010. World Health Organization, Geneva.

Willcox, M., Benoit-Vical, F., Fowler, D., Bourdy, G., Burford, G., Giani, S., Graziose, R., Houghton, P., Randrianarivelojosia, M., Rasoanaivo, P., 2011. Do ethnobotanical and laboratory data predict clinical safety and efficacy of anti-malarial plants? Malar. J. 10, S7. doi:10.1186/1475-2875-10-S1-S7

Willcox, M.L., Bodeker, G., 2004. Traditional herbal medicines for malaria. BMJ 329, 1156-1159. doi:10.1136/bmj.329.7475.1156

Yang, Y.-L., Chang, S.-M., Wu, C.-C., Hsieh, P.-W., Chen, S.-L., Chang, F.-R., Hung, W.-C., Issa, H.H., Wu, Y.-C., 2007. Cytotoxic sesquiterpene lactones from Pseudoelephantopus spicatus. J. Nat. Prod. 70, 1761-1765. doi:10.1021/np070331q

Youn, U.J., Park, E.-J., Kondratyuk, T.P., Simmons, C.J., Borris, R.P., Tanamatayarat, P., Wongwiwatthananukit, S., Toyama, O., Songsak, T., Pezzuto, J.M., Chang, L.C., 2012. Antiinflammatory sesquiterpene lactones from the flower of Vernonia cinerea. Bioorg. Med. Chem. Lett. 22, 5559-5562. doi:10.1016/j.bmcl.2012.07.010 


\begin{tabular}{|c|c|c|c|c|c|c|c|}
\hline $\begin{array}{l}\text { Extracts/ } \\
\text { Compounds }\end{array}$ & $\begin{array}{c}\mathrm{IC}_{50} \\
\text { Promastigotes } \\
\text { L.infantum }\end{array}$ & $\begin{array}{c}\mathrm{IC}_{50} \\
\text { Axenic amastigotes } \\
\text { L.infantum }\end{array}$ & $\begin{array}{c}\mathrm{CC}_{50} \\
\text { Macrophages }\end{array}$ & $\mathbf{S I}$ & $\begin{array}{c}\mathrm{IC}_{50} \\
\text { P. falciparum FcM } 29\end{array}$ & $\begin{array}{l}\mathrm{CC}_{50} \\
\text { VERO }\end{array}$ & $\mathbf{S I * *}$ \\
\hline $\mathrm{H}_{2} \mathrm{O}$ extract & $13.4 \pm 2.6 \mu \mathrm{g} / \mathrm{mL}$ & - & $1.0 \pm 0.2 \mu \mathrm{g} / \mathrm{mL}$ & 0.07 & $3.0 \pm 0.6 \mu \mathrm{g} / \mathrm{mL}$ & $1.7 \pm 0.8 \mu \mathrm{g} / \mathrm{mL}$ & 0.6 \\
\hline EtOH extract & $>50 \mu \mathrm{g} / \mathrm{mL}$ & - & ND & ND & $21.1 \pm 1.2 \mu \mathrm{g} / \mathrm{mL}$ & $2.5 \pm 1.0 \mu \mathrm{g} / \mathrm{mL}$ & 0.1 \\
\hline 2 & $24.1 \pm 4.5 \mu \mathrm{M}$ & $4.7 \pm 1.8 \mu \mathrm{M}$ & $1.4 \pm 0.08 \mu \mathrm{M}$ & 0.06 & $7.8 \pm 1.2 \mu \mathrm{M}$ & $3.7 \pm 1.5 \mu \mathrm{M}$ & 0.5 \\
\hline 3 & $9.5 \pm 0.2 \mu \mathrm{M}$ & $2.0 \pm 1.4 \mu \mathrm{M}$ & $0.9 \pm 0.07 \mu \mathrm{M}$ & 0.09 & $6.9 \pm 0.9 \mu \mathrm{M}$ & $1.8 \pm 0.07 \mu \mathrm{M}$ & 0.3 \\
\hline 5 & $86.3 \pm 13 \mu \mathrm{M}$ & $17.0 \pm 0.6 \mu \mathrm{M}$ & $5.5 \pm 1.9 \mu \mathrm{M}$ & 0.06 & $50 \mu \mathrm{M}(\mathrm{n}=1)$ & $17.6 \pm 8.0 \mu \mathrm{M}$ & 0.4 \\
\hline 6 & $31.5 \pm 3 \mu \mathrm{M}$ & $5.4 \pm 4.4 \mu \mathrm{M}$ & $3.1 \pm 1.0 \mu \mathrm{M}$ & 0.10 & $54.9 \pm 3.4 \mu \mathrm{M}$ & $75.2 \pm 37 \mu \mathrm{M}$ & 1.4 \\
\hline 7 & $>100 \mu \mathrm{M}$ & $68 \pm 14 \mu \mathrm{M}$ & ND & ND & Not stable & $90 \pm 40 \mu \mathrm{M}$ & ND \\
\hline Amphotericin B & $0.03 \pm 0.01 \mu \mathrm{M}$ & $0.34 \pm 0.2 \mu \mathrm{M}$ & $2.5 \pm 0.2$ & 83 & - & $12.2 \pm 2.8 \mu \mathrm{M}$ & - \\
\hline Miltefosine & $8.8 \pm 2.8 \mu \mathrm{M}$ & - & $155.3 \pm 15.2 \mu \mathrm{M}$ & 18 & - & - & - \\
\hline Pentamidine & $0.5 \pm 0.3 \mu \mathrm{M}$ & - & $0.53 \pm 0.57 \mu \mathrm{M}$ & 1 & - & - & - \\
\hline Doxorubicin & - & - & $0.06 \pm 0.04 \mu \mathrm{M}$ & - & - & - & - \\
\hline Chloroquine & - & - & - & - & $549.2 \pm 68 \mathrm{nM}$ & - & - \\
\hline Artemisinin & - & - & - & - & $13.9 \pm 7.7 \mathrm{nM}$ & - & - \\
\hline
\end{tabular}

Table 1 Antileishmanial and antiplasmodial activities of P.spiralis crude extracts and isolated compounds $(2,3,5,6$ and 7$)$, and their cytotoxicity on macrophages and VERO cell lines. Inhibitory Concentration $50 \%\left(\mathrm{IC}_{50}\right)=$ sample concentration inhibiting $50 \%$ of metabolic activity of parasites. Cytotoxic Concentration $50 \%\left(\mathrm{CC}_{50}\right)=$ sample concentration providing $50 \%$ death of macrophages J774A.1 or VERO cells.

*Selectivity Index (SI)= $\mathrm{CC}_{50}$ (macrophages) / IC 50 (promastigotes)

$* * \mathrm{SI}=\mathrm{CC}_{50}(\mathrm{VERO}) / \mathrm{IC} \mathrm{C}_{50}$ (Plasmodium)

\pm : Standard Deviation 

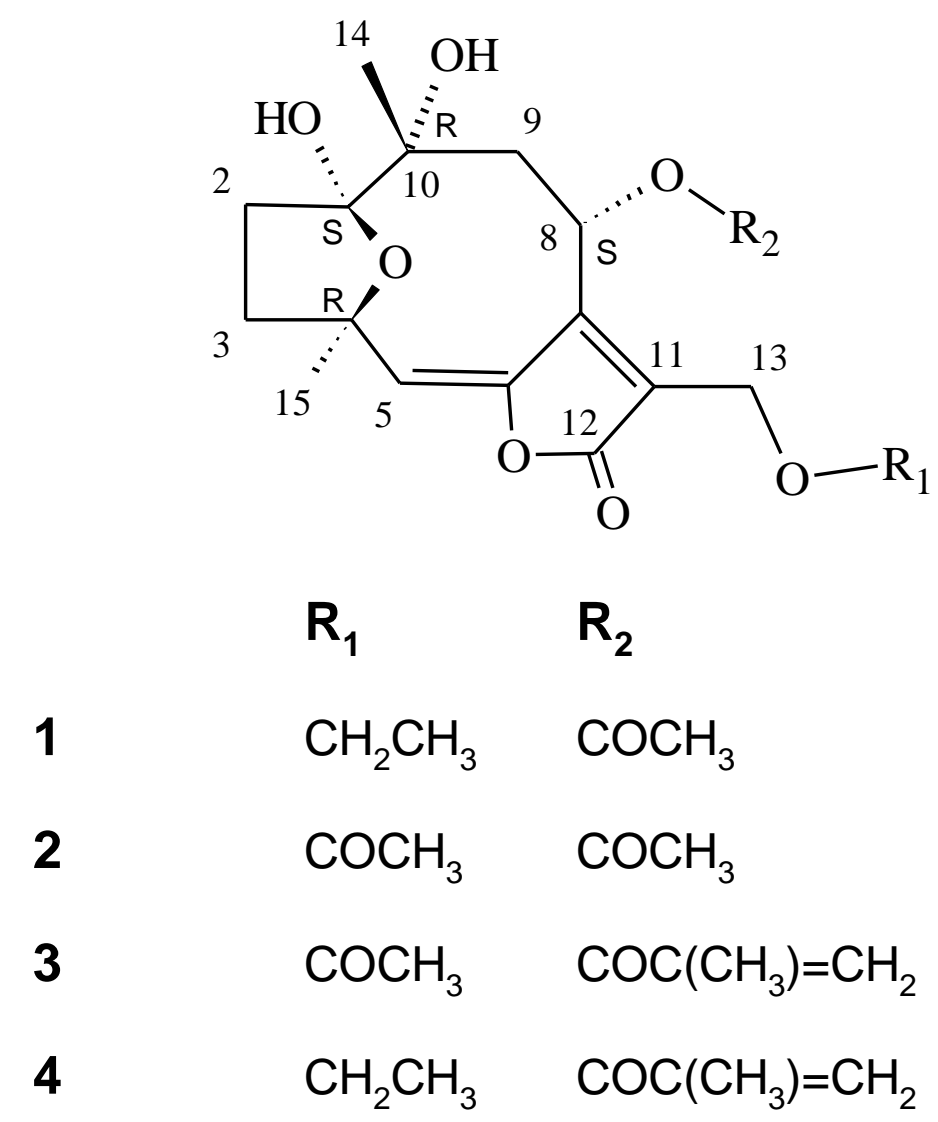

Fig. 1 Isolated compounds from Pseudelephantopus spiralis (Less.) Cronquist

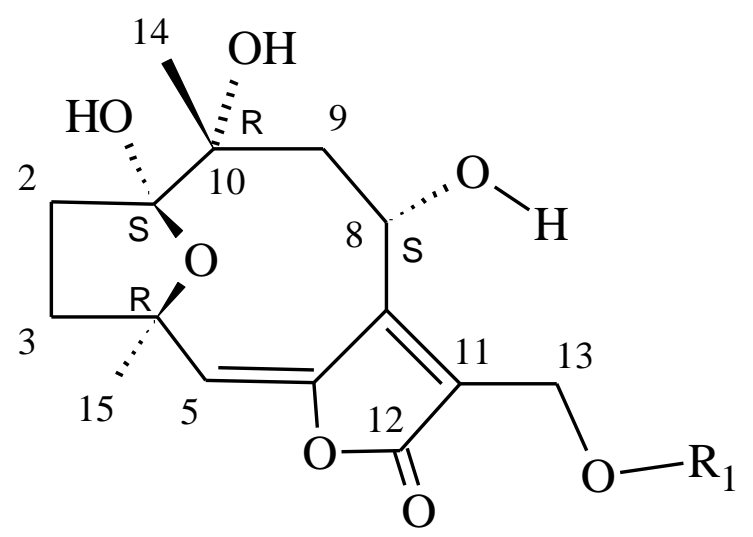

$\mathbf{R}_{1}$

5

6

7
$\mathrm{COCH}_{3}$

$\mathrm{CH}_{2} \mathrm{CH}_{3}$

$\mathrm{H}$ 
